\title{
A Petrographic Study of the Three Forks Formation (Upper Devonian), Williston Basin, North Dakota: Based on Thin Section Analysis, XRD and SEM
}

\author{
Richard Ashu \\ Harold Hamm School of Geology and Geological Engineering, 101 Leonard Hall, 81 Cornell Street, Stop 8358, \\ University of North Dakota, Grand Forks, ND 58202-8358, USA \\ Correspondence should be addressed to Richard Ashu; richard.ashu@my.und.edu
}

Received 4 February 2014; Accepted 25 March 2014; Published 17 April 2014

Academic Editor: David T. A. Symons

Copyright (C) 2014 Richard Ashu. This is an open access article distributed under the Creative Commons Attribution License, which permits unrestricted use, distribution, and reproduction in any medium, provided the original work is properly cited.

\begin{abstract}
Deeply buried below 8,000 ft, the Three Forks Formation in North Dakota displays a variety of interesting diagenetic characteristics including dolomitization and hematite precipitation. Samples from three lithofacies are analyzed by thin section and SEM petrography and combined bulk and clay XRD analyses. Key aspects controlling the porosity and permeability of this formation are revealed by focusing on the detail mineralogy, rock type and diagenetic mineral distribution, and overall reservoir quality. Results prove that the Three Forks mineralogy is dominated by dolomite, along with substantial hematite, monocrystalline quartz, and mica flakes with trace feldspar, calcite, and pyrite. Clays mainly consist of illite together with minor chlorite and kaolinite and are associated with the scattered clasts. The reservoir quality is controlled by intercrystalline, rare microvuggy, and microporosity types that result from diagenetic and depositional events. Three stages of the dolomitization process are identified and discussed. Our hypothesis is that dolomitization commenced soon after deposition and was pervasive as no original carbonate texture is detectable.
\end{abstract}

\section{Introduction}

The Three Forks Formation exists within the Williston Basin, occupying nearly two-thirds of North Dakota, underlying the Lower Mississippian Bakken Formation, and overlying the Upper Devonian Birdbear Formation (Figure 1). The Three Forks Formation is one of the most unpredictable petroleum systems within the Williston Basin with a combination of carbonates, clays, organics, and detrital material of poor to moderate reservoir quality, reflecting its depositional and postdepositional fabric. This study serves as an attempt to provide critical information on the prospectivity, in terms of key diagenetic processes that operate within the Three Forks, based on a derived dataset of results from thin section analysis, X-ray diffraction (XRD), and scanning electron microscopy (SEM). The aims of this study are to determine the following: (1) mineralogical composition, (2) differences in texture, (3) framework fabric, (4) sequence of diagenetic events, (5) pore system, and (6) reservoir quality of the Three Forks in three identified lithofacies [1]. Close-up photomicrographs are provided to stress (1) preserved primary and secondary pore types, (2) cements, (3) sedimentary structures, (4) fractures, and (5) pore plugging hematite. A brief summary of sample information, rock type, lithology, thin section porosity, analysis types, original texture, and reservoir quality are presented as Table 1. Results exemplify the need for a more comprehensive study as much is still undecipherable. It is hoped that this study will fuel further, targeted multifield, and regional studies to provide insight into the flow-controlling reservoir heterogeneities that increasingly challenge the drive to optimize hydrocarbon recovery within the formation.

\section{Materials and Methods}

The data and interpretations for this study were based upon a detailed petrographic examination of core samples from three (3) lithofacies (Figure 2) from the top, middle, and lower Three Forks Formation in wells 19951 and 19918 supplied by the Wilson M. Laird Core and Sample Library of the North Dakota Geological Survey [2]. Two (2) samples from each 


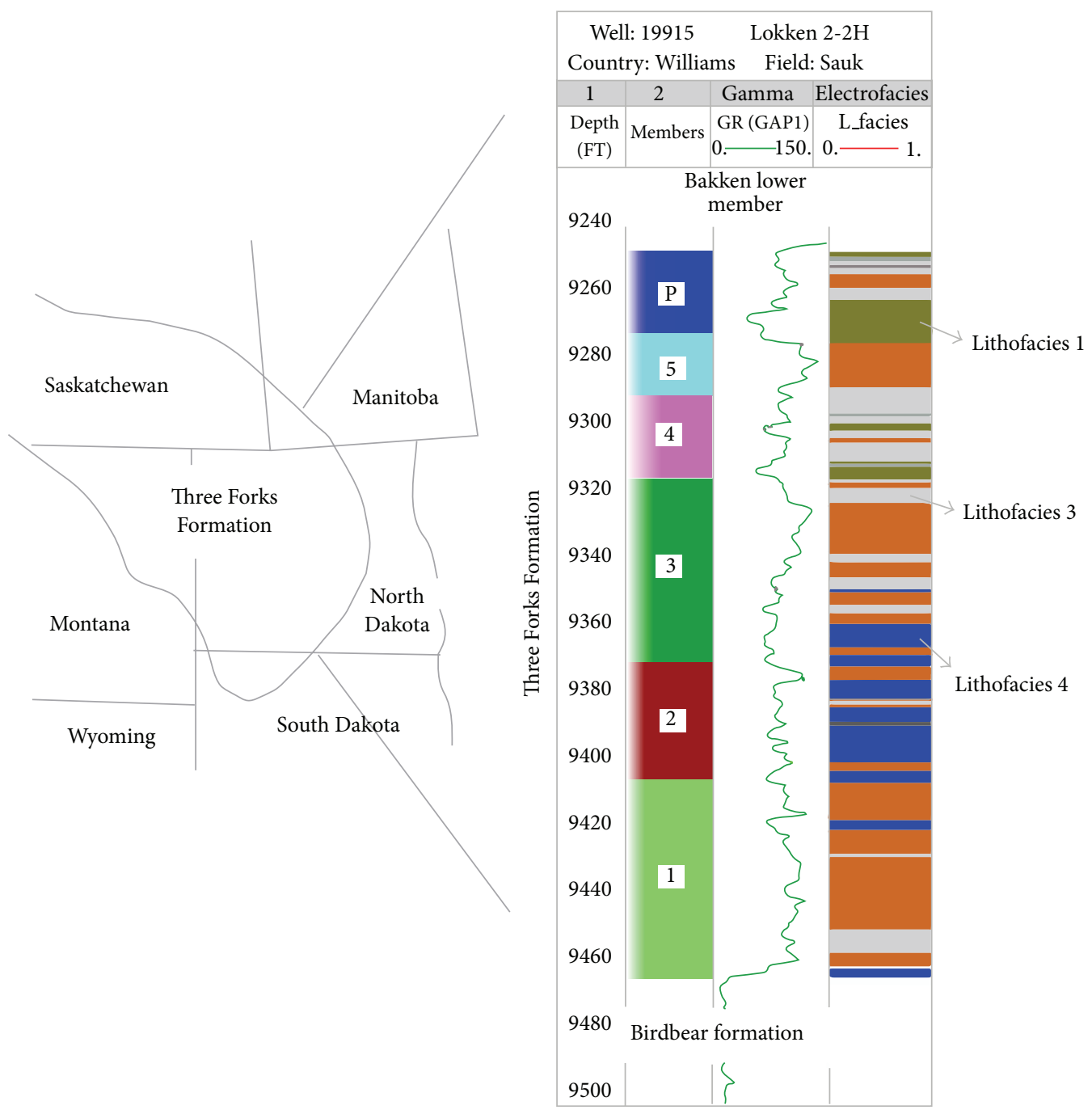

FIgURE 1: Extent and stratigraphic position of the Three Forks Formation showing members 1 to 5, the Pronghorn Member (P), and sample locations.

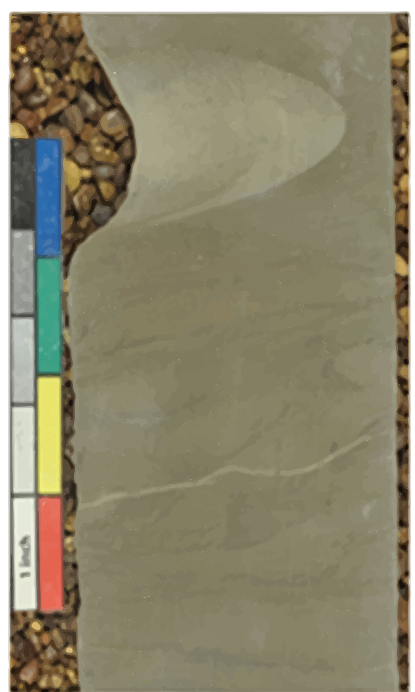

Facies 1

(a)

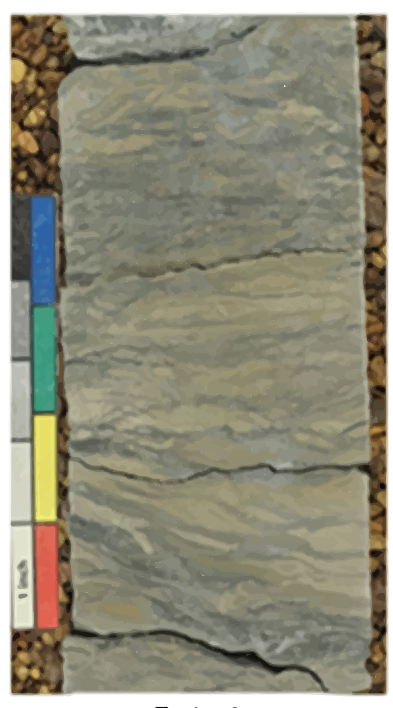

Facies 3

(b)

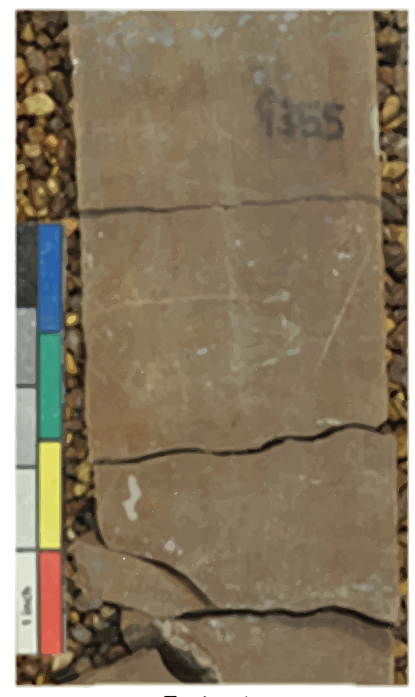

Facies 4

(c)

Figure 2: Selected lithofacies for petrographic analysis, from the top, middle, and lower Three Forks. 


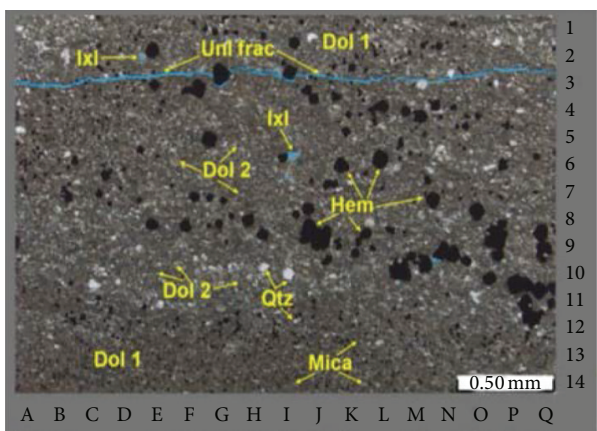

(a)

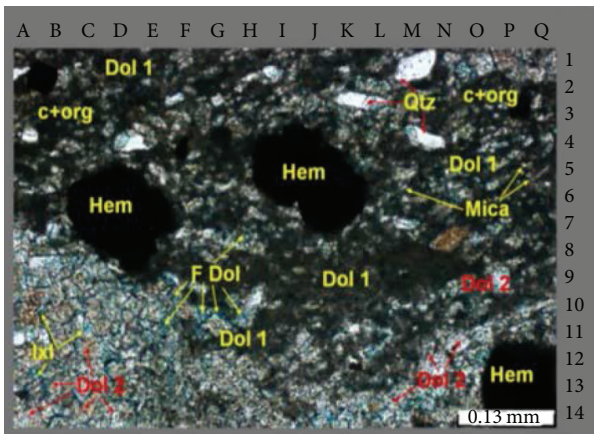

(c)

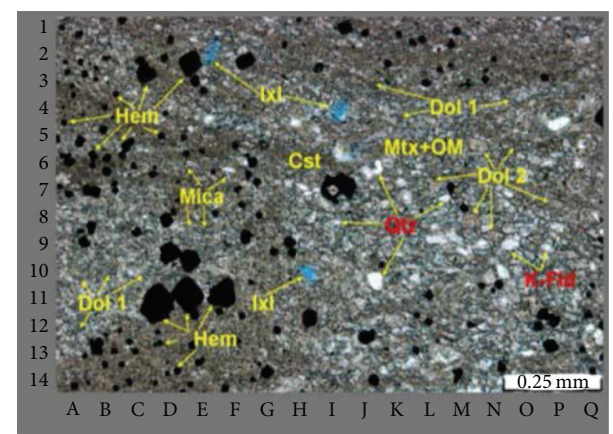

(b)

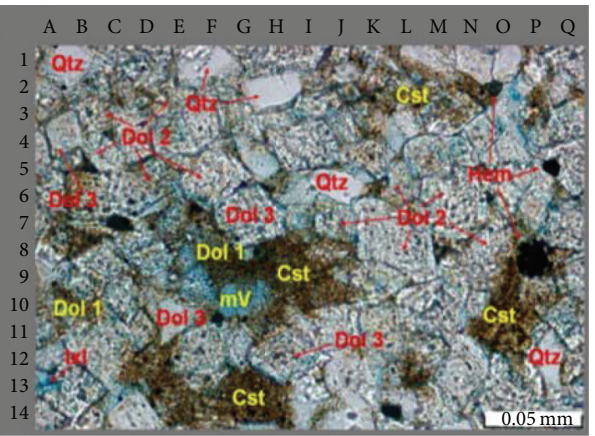

(d)

Figure 3: Thin section photomicrographs of lithofacies 1. (a) x50ppl, 1st (Dol 1) and 2nd (Dol 2) generation replacement dolomite, scattered monocrystalline quartz (Qtz), unloading fracture (Unl frac), and intercrystalline porosity (Ixl); (b) x100ppl; (c) x200ppl hematite (Hem) occluding pores and as microblebs replacing Dol 1 and Dol 2 rhombs; (d) x400ppl, dissolution microvugs (mV) and clast rimmed with Dol 3 crystals.

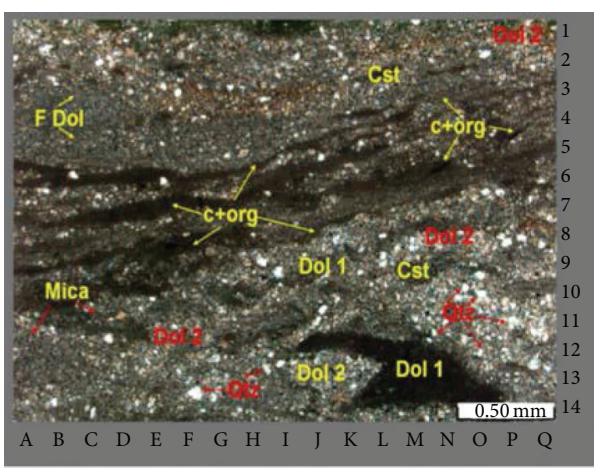

(a)

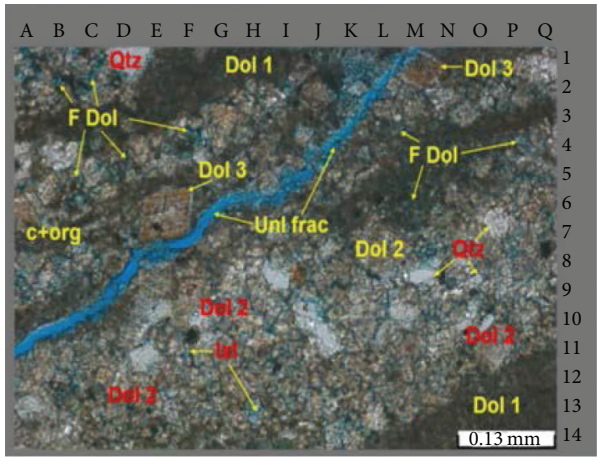

(c)

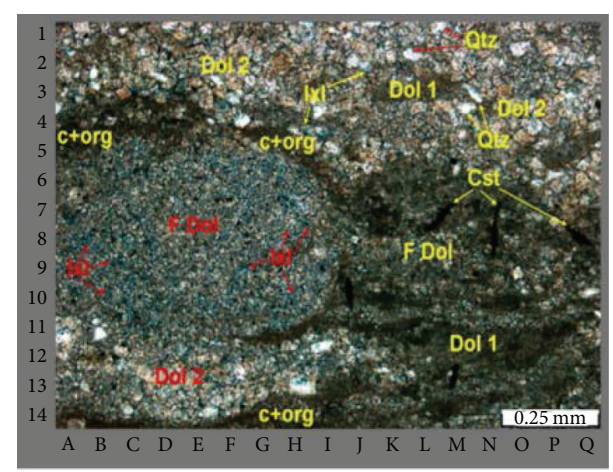

(b)

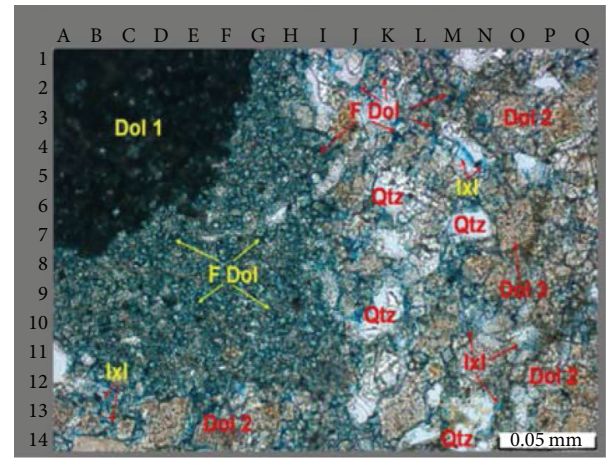

(d)

FIGURE 4: Photomicrographs of lithofacies 3. (a) x50ppl, ferroan (F Dol), nonferroan dolomites, associated minerals, and matrix partings (c+org); (b) x100ppl, anhedral (Dol 1) to subhedral (Dol 2) dolomite; (c) x200ppl, unloading fracture (Unl frac), associated minerals, and intercrystalline pores (Ixl); (d) x400ppl, clearly showing the 1st (Dol 1), 2nd (Dol 2), and 3rd (Dol 3) generation dolomites that occlude the intercrystalline pores and limit the interconnectivity. 


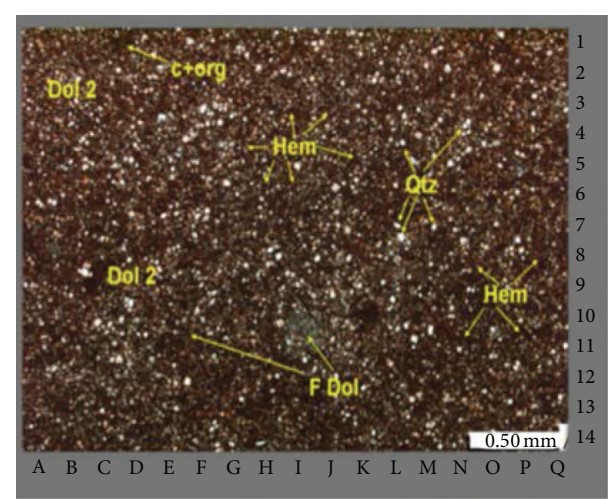

(a)

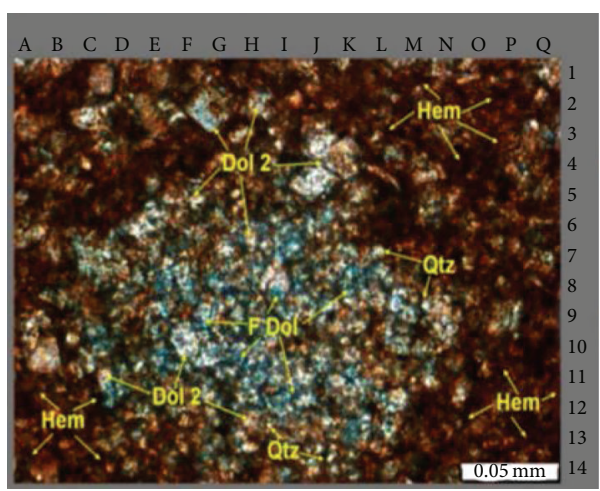

(c)

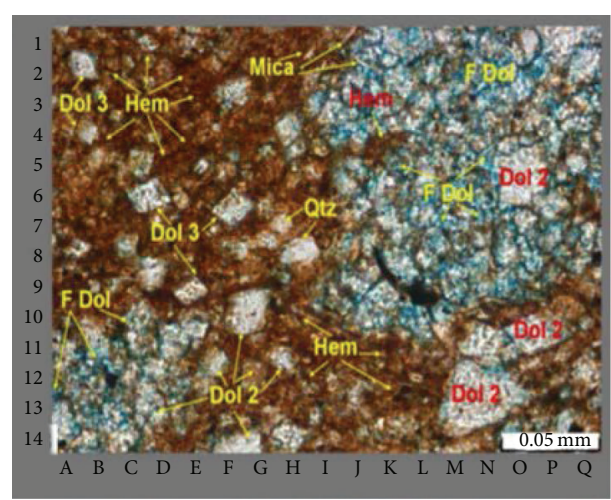

(b)

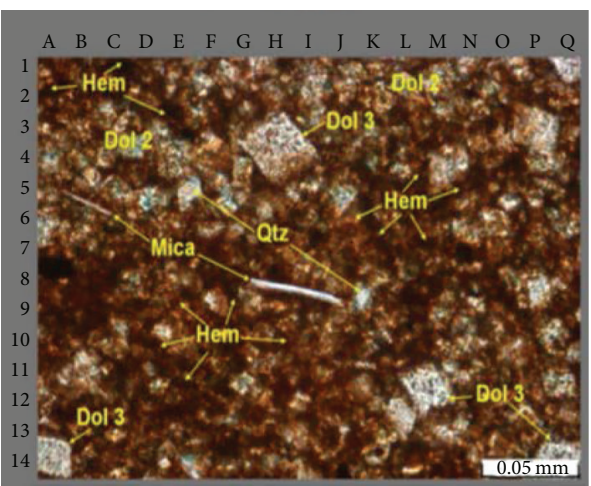

(d)

FIGURE 5: Photomicrographs of lithofacies 4. (a) x50ppl, very fine to medium crystalline dolomite rhombs surrounded by deep red hematite cement plus minor amounts of clasts; (b, c, d) x400ppl, ferroan and nonferroan subhedral (F Dol, Dol 2) and euhedral (Dol 3) dolomite rhombs and monocrystalline quartz.

TABLE 1: Summary of sample information.

\begin{tabular}{lcccr}
\hline $\begin{array}{l}\text { Sample stratigraphic } \\
\text { position }\end{array}$ & Rock type & TS* porosity (\%) & Analysis type & Original texture \\
\hline $\begin{array}{l}\text { Lithofacies } 1 \\
\text { (top) }\end{array}$ & Silty/sandy dolomite & $3 \%$ & TS, SEM, and XRD & Dolomudstone \\
$\begin{array}{l}\text { Lithofacies } 3 \\
\text { (middle) }\end{array}$ & Silty/sandy dolomite & $2 \%$ & TS, SEM, and XRD & Dolomudstone \\
$\begin{array}{l}\text { Lithofacies } 4 \\
\text { (lower) }\end{array}$ & Silty/sandy dolomite & Trace & TS, SEM, and XRD & Dolomudstone \\
\hline
\end{tabular}

${ }^{*}$ TS: thin section; SEM: scanning electron microscopy; XRD: combined bulk and clay XRD Analysis; RQ: reservoir quality.

facies are chosen to obtain maximum representation. Small portions of fresh samples were analyzed by bulk and clay XRD techniques using the fingerprinting approach [3,4]. Six (6) XRD samples (two from each facies) are taken from the same position as the thin section samples. Thin sections are prepared following standard petrographic procedures to a size of $30 \mu \mathrm{m}$. Samples had been impregnated with blue epoxy and stained with a combined carbonate stain of Alizarin Red-S solution and potassium ferricyanide [5, 6]. Visual estimates of grains and cements are obtained by point counting (300 points). Small pieces of each sample are examined by SEM to highlight the occurrence, distribution, and origin of micropores, plus constituent minerals and their textural features. Energy dispersive X-ray (EDX) analysis is also carried out to get the elemental composition of the samples.

\section{Results and Discussion}

3.1. The Bulk and Clay XRD. Results of the combined bulk and clay XRD analysis are presented as in Table 2 . The nonclay portions of the samples are dominated by dolomite $(56 \%$ to $60 \%$ ) along with lesser quartz (14\% to $16 \%)$, with minor amounts of potassium feldspar (2\% to 3\%) and plagioclase feldspar ( $1 \%$ to $2 \%)$, calcite ( $1 \%$ to $2 \%)$, hematite (trace to $1 \%$ ), 


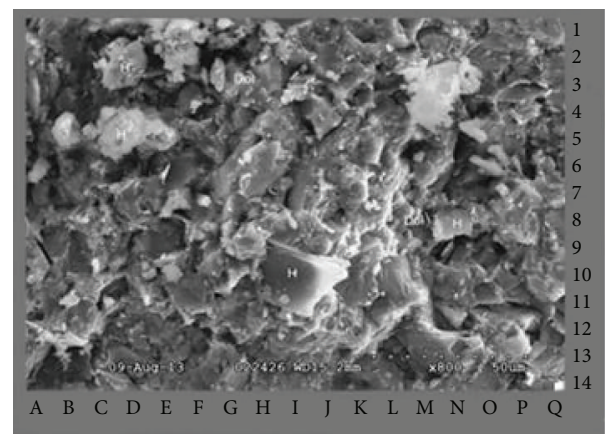

Facies 1

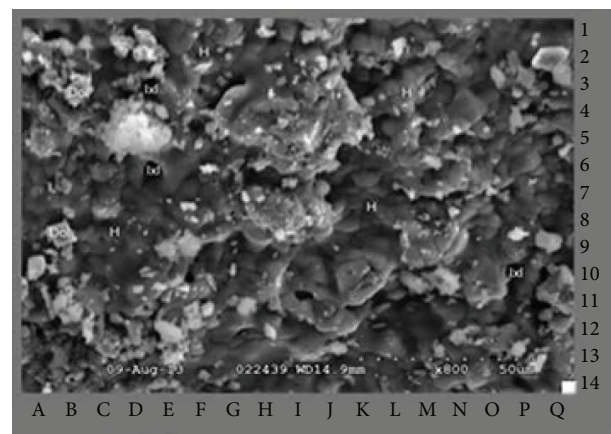

Facies 3

(a)

(b)

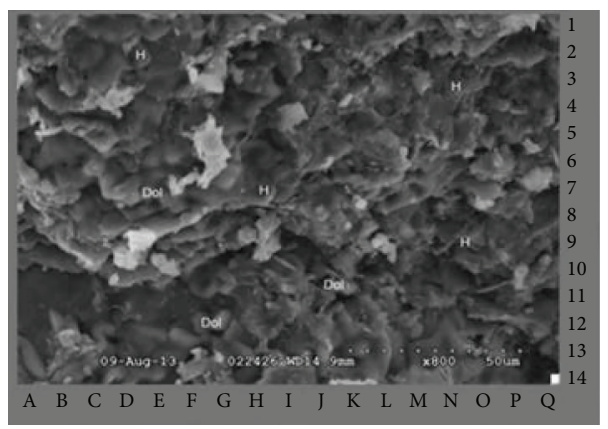

Facies 4

(c)

FIGURE 6: SEM photomicrographs of the Three Forks showing the distribution of very fine to medium crystalline dolomite rhombs (Dol) and small, disc shaped authigenic hematite cements $(\mathrm{H})$ in all samples $(\mathrm{a}, \mathrm{b}, \mathrm{c})$. The intercrystalline (Ixl, A: E4, N5) porosity is mainly obstructed by the precipitation of anhedral to subhedral dolomite rhombs and subordinately by hematite cements.

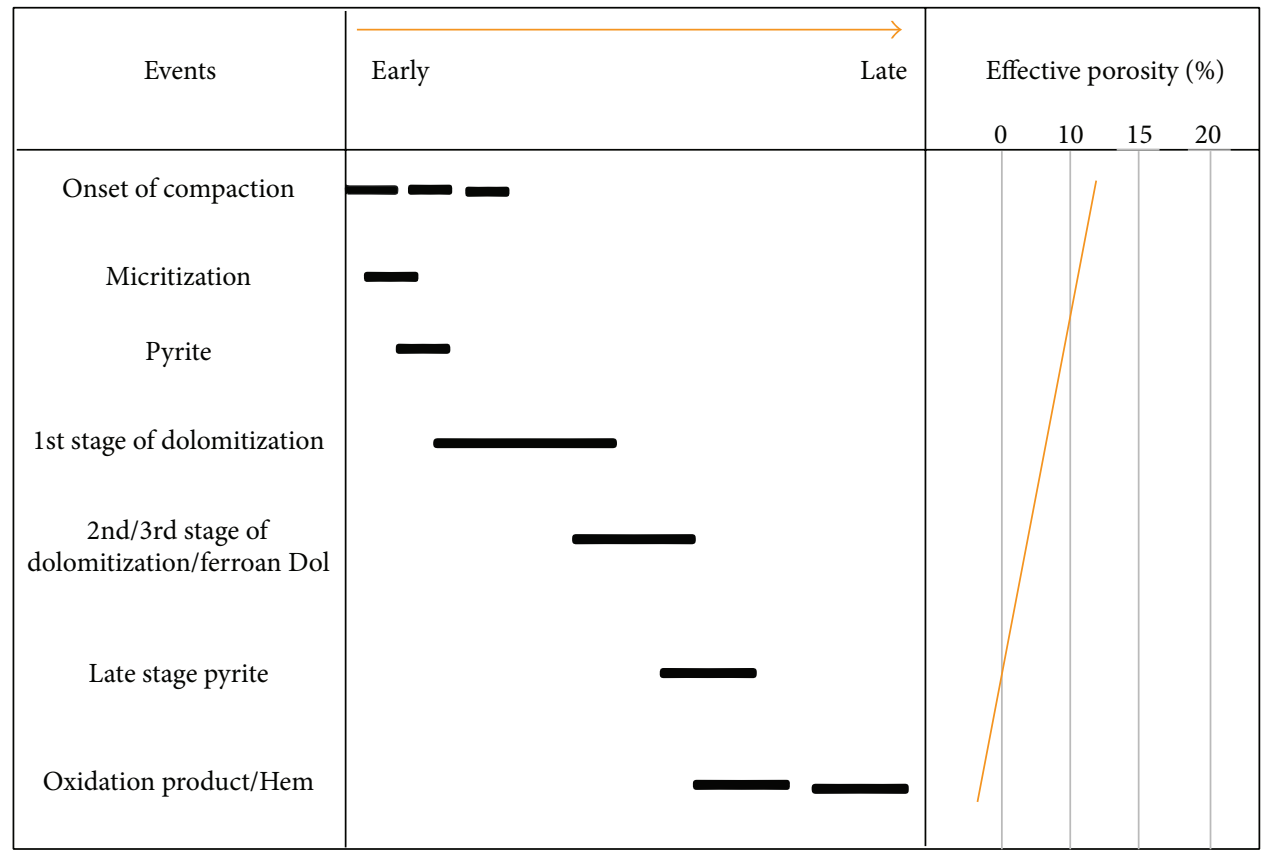

Figure 7: Paragenetic sequence of diagenetic events for the Three Forks Formation based on three (3) lithofacies from wells 19915 and 19918. 
TABLE 2: Summary of Bulk and Clay XRD Analysis.

\begin{tabular}{|c|c|c|c|c|c|c|c|c|c|c|c|c|c|}
\hline \multirow{2}{*}{ Facies ID } & \multirow{2}{*}{ Type of analysis } & \multirow{2}{*}{ Wt.\% } & \multirow{2}{*}{ Qtz } & \multirow{2}{*}{ Plag } & \multirow{2}{*}{ K-Feld } & \multirow{2}{*}{ Cal } & \multirow{2}{*}{ Dol } & \multirow{2}{*}{ Hem } & \multirow{2}{*}{ Sider } & \multicolumn{3}{|c|}{$\leftarrow$ Clays $\rightarrow$} & \multirow{2}{*}{ Total clay } \\
\hline & & & & & & & & & & Kaol & Chl & Ill & \\
\hline \multirow{3}{*}{1} & Bulk & 91.27 & 16 & 2 & 2 & 1 & 65 & 1 & 0 & 2 & 1 & 10 & 13 \\
\hline & Clay & 8.73 & 8 & 1 & 1 & 0 & 12 & 0 & 2 & 12 & 10 & 54 & 76 \\
\hline & Bulk + clay & 100 & 15 & 2 & 2 & 1 & 60 & 1 & TR & 3 & 2 & 14 & 19 \\
\hline \multirow{3}{*}{3} & Bulk & 93.50 & 17 & 1 & 2 & 1 & 61 & 0 & 0 & 3 & 3 & 12 & 18 \\
\hline & Clay & 6.50 & 8 & 1 & 2 & 0 & 7 & 1 & 3 & 12 & 16 & 50 & 78 \\
\hline & Bulk + clay & 100 & 16 & 1 & 2 & 1 & 58 & TR & TR & 3 & 4 & 15 & 22 \\
\hline \multirow{3}{*}{4} & Bulk & 95.15 & 15 & 2 & 3 & 2 & 58 & 1 & 0 & 3 & 3 & 13 & 19 \\
\hline & Clay & 4.85 & 4 & 1 & 1 & 0 & 6 & 1 & 1 & 10 & 25 & 51 & 86 \\
\hline & Bulk + clay & 100 & 14 & 2 & 3 & 2 & 56 & 1 & $\mathrm{TR}$ & 3 & 4 & 15 & 22 \\
\hline
\end{tabular}

Bulk fraction: greater than 3 microns size fraction.

Clay fraction: less than 3 micron size fraction.

Bulk and clay: mathematical recalculation including the bulk and clay fraction representing the whole sample.

Total clay: sum of the clay minerals (may include authigenic and matrix clays plus clays in rock fragments).

Dol: dolomite; Olivine: olivine; Plag: plagioclase feldspar; Hem: hematite; Ill: illite; Hema: hematite; Kaol: kaolinite; Sider: siderite; Chl: chlorite; K-feld: potassic feldspar; Cal: calcite; Qtz: quartz.

Tr: trace; detectable, but not measurable (0-1\%).

and trace siderite. The clay portion consists of illite (14\% to $15 \%)$, together with chlorite ( $2 \%$ to $4 \%$ ) and kaolinite (3\%). The clay fraction $(<3 \mu \mathrm{m}$ fraction that best represent finer matrix clays) ranges from $4.85 \%$ to $8.73 \%$ of the total weight volume of the samples and consists of ( $76 \%$ to $86 \%)$ clay minerals. Pore-filling kaolinite is present in all samples and together with chlorite and illite is interpreted as terrigenous, weathered products of plagioclase and K-feldspar.

3.2. Thin Section Analysis and Interpretation. The thin section petrographic summary is given in Table 3 . Three main stages of dolomitization are observed in these samples. The first stage or dolomite type 1 (Dol 1) is classified as very fine to fine crystalline $(<62.5 \mu \mathrm{m})$ generally anhedral and unimodal dolomite consisting of tightly to loosely interlocked crystals (Figures 3-5) that replace the matrix of the original rock. Intercrystalline porosity occurs in poor amounts in dolomite type 1 . The second stage of dolomitization (Dol 2) which replaces the earlier formed dolomite is the most abundant ( $26 \%$ to $35 \%)$ and generally better formed subhedral to euhedral dolomite rhombs ( $>62.5 \mu \mathrm{m}$ or medium crystalline) that cement the larger intercrystalline pores (Figures 3-5).

Also, this dolomite occasionally presents a sucrosic texture that may have resulted to a certain degree from the bulk volume shrinkage that accompanies calcite replacement by dolomite or from the dissolution of residual calcite during the final stages of dolomitization [7]. Rare medium to coarsely crystalline euhedral dolomite cements are considered last stage (3rd generation) dolomite cement and are present mostly in the porous areas (Dol 3) consisting of dolomite rhombs (1\% to $3 \%$ ). These dolomite rhombs often have saddle morphology and cement the intercrystalline pores (Figures 4 and 5). Both the 2nd and 3rd generation dolomites are occasionally turquoise stained, highlighting the presence of iron rich dolomite.
3.2.1. Lithofacies 1. This facies has a thin section porosity of $3 \%$. At moderate magnification view, this facies consists of very fine to medium crystalline dolomite rhombs (Figure 3(a)). Monocrystalline quartz and trace amounts of feldspar grains are the detrital sand grains that are scattered throughout. Overall, the replacement dolomite is dominated by anhedral to subhedral interlocking very fine crystalline dolomite rhombs, with substantial amounts of recrystallized fine crystalline 2nd stage dolomite and lesser late stage void rimming fine to medium crystalline euhedral rhombs. The mineralogy of this sample is dominated by dolomite (54\%) with moderate amounts of matrix material (20\%), hematite (13\%), and quartz (10\%) along with minor muscovite (Mica, 3\%), plus trace calcite, feldspar, and pyrite. Moderate hematite and trace pyrite are the noncarbonate diagenetic minerals that substantially occlude pores. Hematite also occurs as microblebs and replaces the clay matrix and the anhedral-subhedral dolomite rhombs. Visible porosity is represented by small size isolated minor intercrystalline (2\%) and microvuggy (1\%) pores. Microfracturing is quite common in this facies and may probably result from unloading fracture (Figure 3(a)). Figures 3(b)-3(d) highlight pervasive dolomitization which appears to have created all the visible small isolated intercrystalline pores. Dolomite rhombs are in places slightly ferroan. The hematite is interpreted as the final weathering product of pyrite or siderite formed during the last diagenetic step [8]. Minor amounts of clasts (clay and organics) generally occur as lenses and create permeability barriers.

3.2.2. Lithofacies 3. Facies 3 consist of very fine to medium crystalline dolomite rhombs and monocrystalline quartz and feldspar detrital sand grains (Figure 4(a)). Photomicrographs (Figures 4(b)-4(d)) highlight the replacement dolomite in this facies, dominated by ferroan and nonferroan anhedral to 
TABLE 3: Thin section petrographic summary of three dolomitic samples from Facies 1, 2, and 3 of the Three Forks Formation.

\begin{tabular}{|c|c|c|c|c|}
\hline Facies ID & & 1 & 2 & 3 \\
\hline \multirow{6}{*}{ Mineralogy } & $\begin{array}{l}\text { Calcite, feldspar, } \\
\text { pyrite }\end{array}$ & $\mathrm{TR}$ & TR & TR \\
\hline & Dolomite & 54 & 57 & 40 \\
\hline & Quartz & 10 & 11 & 5 \\
\hline & Mica & 3 & 2 & 2 \\
\hline & Hematite & 13 & 10 & 37 \\
\hline & $\begin{array}{l}\text { Clay + organic } \\
\text { matter }\end{array}$ & 20 & 20 & 16 \\
\hline \multicolumn{2}{|c|}{ Total rock volume (\%) } & 100 & 100 & 100 \\
\hline \multirow{4}{*}{$\begin{array}{l}\text { Detrital } \\
\text { grains }\end{array}$} & Quartz & 10 & 11 & 5 \\
\hline & Feldspar & TR & TR & TR \\
\hline & Mica & 3 & 2 & 2 \\
\hline & Total & 13 & 13 & 7 \\
\hline \multirow[t]{2}{*}{ Matrix } & $\begin{array}{l}\text { Clay and } \\
\text { organics }\end{array}$ & 20 & 20 & 16 \\
\hline & Total & 20 & 20 & 16 \\
\hline \multirow{7}{*}{$\begin{array}{l}\text { Pore-filling } \\
\text { cement }\end{array}$} & Calcite & $\mathrm{TR}$ & $\mathrm{TR}$ & $\mathrm{TR}$ \\
\hline & $\begin{array}{l}\text { 3rd/euh } \\
\text { dolomite }\end{array}$ & 1 & 1 & 3 \\
\hline & $\begin{array}{l}\text { 2nd/sub } \\
\text { dolomite }\end{array}$ & 35 & 26 & 29 \\
\hline & 1st/anh dolomite & 10 & 13 & TR \\
\hline & Fe-dolomite & 8 & 17 & 8 \\
\hline & Hematite & 13 & 10 & 37 \\
\hline & Total & 67 & 67 & 77 \\
\hline \multicolumn{2}{|c|}{ Replacement Pyrite } & TR & TR & TR \\
\hline \multicolumn{2}{|c|}{ Total rock volume (\%) } & 100 & 100 & 100 \\
\hline \multicolumn{2}{|c|}{ Crystal texture (matrix) } & Anh & Anh & - \\
\hline \multicolumn{2}{|c|}{ Crystal texture (cement) } & Anh-Euh & Anh-Euh & Anh-Euh \\
\hline \multicolumn{2}{|c|}{ Original texture } & Mudstone & Mudstone & Mudstone \\
\hline \multirow{3}{*}{ Porosity } & Intercrystalline & 2 & 2 & TR \\
\hline & Microvuggy & 1 & - & - \\
\hline & $\begin{array}{l}\text { Total TS } \\
\text { porosity (\%) }\end{array}$ & 3 & 2 & TR \\
\hline $\begin{array}{l}\text { Reservoir } \\
\text { Quality }\end{array}$ & & P-M & P-M & $\mathrm{P}$ \\
\hline
\end{tabular}

Euh: euhedral; Sub: subhedral; Anh: anhedral; TR: trace; G: good; M: moderate; P: poor.

subhedral interlocking anhedral (Dol 1) to subhedral (Dol 2) dolomite rhombs. The 3rd generation void rimming euhedral rhombs are locally observed in the porous areas and occlude the intercrystalline pores and limit the interconnectivity (Figures 4(c) and 4(d); Dol 3). The mineralogy of this sample is dominated by dolomite (57\%) with moderate amounts of matrix material (20\%), quartz (11\%), and hematite $(10 \%)$ along with minor muscovite (Mica, 2\%), plus trace calcite, feldspar, and pyrite. A major distinguishing characteristic of this facies is the presence of matrix partings pyritized organic matter and clays (c+org) (Figure 4(a)). Visible porosity is represented by small size isolated minor intercrystalline
(2\%) pores. Minor noneffective microporosity occurs in the "matrix" dolomite. Also, clay and organics (Cst) generally occur as lenses of shale and elongated clasts (Figures 4(a) and $4(\mathrm{~b}))$.

3.2.3. Lithofacies 4 . This facies is characterized by very fine to medium crystalline dolomite rhombs surrounded by deep red hematite cement (Figure 5). Similar to facies 1 and 3, detrital sand grains consist of monocrystalline quartz and trace amounts of feldspar but the replacement dolomite $s$ dominated by ferroan and nonferroan, subhedral recrystallized 2nd stage dolomite (Figure 5(a)). This facies also contains more hematite than the others. Mineralogically, this facies is dominated by dolomite (40\%) and hematite (37\%) cements with moderate amounts of matrix material (16\%) and lesser quartz (5\%) along with minor muscovite (2\%), plus trace calcite, feldspar, and pyrite. The original carbonate texture would have been mudstone. In this facies hematite cement appears to have occluded all the intercrystalline pore spaces. Long, thin detrital grains of mica (Figures 5(b) and $5(d))$ are also present.

\section{SEM Analysis and Interpretation}

SEM reveals that authigenic hematite is mostly small, round, or disc shaped, and coarsely crystalline (Figure 6). The coarser hematite occurs either as irregular platy crystals or as well-developed hexagonal crystals (similar in appearance to kaolinite crystals) and is dark red to black in reflected light. Dolomite shows abraded subhedral, rhombic termination which is strongly suggestive of resedimentation [9]. Scattered hematite inclusions within these abraded dolomite rhombs and detrital quartz grains are responsible for the reddishbrown coloration of these facies. The EDX spectra illustrating dolomite and hematite cement show that the major elements of hematite are primarily iron $(\mathrm{Fe})$ and that of dolomite as $(\mathrm{Ca}, \mathrm{Mg})$, with additional $\mathrm{Si}, \mathrm{Al}$, and $\mathrm{K}$ from the detection of adjacent quartz grains, plus illite and kaolinite clays.

\section{Diagenetic History}

Diagenetic features, in a paragenetic sequence, include onset of compaction, precipitation of calcite and pyrite, dolomitization or dolomite cement in pores, and hematite precipitation (Figure 7). Compaction of the sediment sets in immediately after deposition and increases during burial due to rising lithostatic stress. Early stage of compaction reduces volume and porosity of sediment by expelling interstitial waters and framework becomes slightly compacted. Precipitation of pyrite occurs in two stages. The first stage pyrite precipitated in early reducing conditions, occluding pores and replacing matrix clays while the later stage pyrite is locally precipitated into the earlier formed dolomite rhombs. We therefore hypothesize that pervasive dolomitization, caused by the influx of magnesium rich fluids, took place shortly after deposition. The dolomite 1 mimics the original finegrained limestone during replacement resulting in a very fine to finely crystalline texture. Euhedral dolomite cement 
TABLE 4: Reservoir quality and porosity controlling factors of the Three Forks Formation.

\begin{tabular}{lccclcc}
\hline Sample ID & Location & Pore types & Tin section porosity (\%) & Main $\phi$ Controls & Minor $\phi$ Controls & Reservoir quality \\
\hline 1 & Top & Ixl, mV, mP & 3 & Comp, Dol, Hem & Cal, Clasts, Py & P-M \\
3 & Middle & Ixl, mP & 2 & Comp, Dol, Hem & Cal, Clasts, Py & P-M \\
4 & Lower & Ixl, mP & Trace & Hem, Comp, Dol & Clasts, Py & P \\
\hline
\end{tabular}

Pore types: Ixl: intercrystalline; $\mathrm{mP}$ : microporosity; $\mathrm{mV}$ : microvuggy.

Reservoir quality: P: poor; M: moderate; G: good.

Main $\phi$ Controls: Dol: dolomitization; Py: pyrite; Cal: calcite; Hem: hematite.

Clast: clay or dolomicrites rich clast.

Comp: mechanical compaction.

is present mainly as finely to medium crystalline rhombs that fringes interparticle pores and microvugs at a later stage of diagenesis. Local ferroan dolomite precipitation occurs at the same time as the euhedral dolomite rhombs. Zonation and overgrowths of dolomite rhombs are rare. Primary porosity is significantly reduced by dolomite cement. Hematite is the weathering and oxidation product is the last diagenetic step.

\section{Porosity, Permeability, and Reservoir Quality}

Data from core analysis suggests average porosity values of $8 \%$ and permeability of $0.016 \mathrm{mD}[1]$. Poor amounts of intercrystalline (trace to $2 \%$ ) and microvuggy (1\%; Facies 1 only) porosities, plus microporosities, are the only visible pore types. The intercrystalline pores are mostly isolated and are poor to moderately interconnected. The interconnection of the pore system in these facies is limited mostly by the abundance and distribution of dolomite and hematite cements. Trace pyrite cement which is irregularly distributed also occludes pores and limits their interconnectivity. Scattered disrupted lamina in portions of Facies 1 and Facies 3 make the heterogeneous distribution of pores and causes local isolation of intercrystalline pores. In places, the moderately connected intercrystalline pores are separated or bounded by tight dolomicrite rich laminae (Figures 3(c) and 4(a)$4(\mathrm{c}))$. The small pore throats and poor interconnectivity of these pores will experience high capillary pressure and are therefore ultimately responsible for the low permeability values obtained by routine core analysis. Overall the reservoir quality is controlled by both diagenetic (dolomitization and precipitation of hematite) and the depositional events (matrix, grain sizes, or scattered clasts). Table 4 summarizes the reservoir quality and the porosity controlling factors (major and minor) for the three Three Forks Formation facies.

\section{Conclusions}

The petrological studies of samples from three facies representing the top, middle, and lower portions of the Three Forks were analyzed by thin section and SEM petrography and combined bulk and clay XRD analyses. The results have revealed that the Three Forks Formation is dominated by dolomite, clays, quartz, K-feldspar, plagioclase, calcite, hematite, and siderite in order of abundance. Dolomitization
TABLE 5: Wells used in this study.

\begin{tabular}{lcccc}
\hline ID & API & Name & County & Field \\
\hline 19918 & $33-053-03358$ & Charlotte 1-22H & McKenzie & Banks \\
19951 & $33-105-02037$ & Lokken 2-2H & Williams & Sauk \\
\hline
\end{tabular}

Obtained from the Wilson M. Laird Core and Sample Library of the North Dakota Geological Survey, 2013 [2].

is pervasive and precipitated in three stages and appears to have created all the visible small intercrystalline pores. In addition, moderate to abundant hematite appears as microblebs that stains dolomite rhombs and clay matrix and occurs as intercrystalline and or microvuggy pores occluding cement. Rare pyrite also locally replaces dolomite rhombs. The combined bulk and clay rock composition show that the clays mainly consist of illite, chlorite, and kaolinite. SEM examination reveals that authigenic hematite is mostly small, round, or disc shaped coarsely crystalline. The reservoir quality of this formation is considered to be poor to moderate. Potential reservoir problems include (1) heterogeneity of the pore system due to abundant disrupted laminae, (2) potential acid sensitivity of iron-bearing minerals, (3) the sensitivity of calcium carbonate (both the dolomite and calcite) to hydrofluoric acid, and (4) migration of carbonate, organic matter, kaolinite, and illite clay fines to pore throat blocking positions.

\section{Appendix}

See Table 5.

\section{Conflict of Interests}

The author declares that there is no conflict of interests regarding the publication of this paper.

\section{References}

[1] R. Ashu, Stratigraphy, depositional environments and petroleum potential of the Three Forks Formation-Williston Basin, North Dakota [Ph.D. thesis], University of North Dakota, Grand Forks, ND, USA, 2014.

[2] North Dakota Geological Survey-Wilson M. Laird Core \& Sample Library, Grand Forks, ND, USA, 2013. 
[3] R. G. Hardy and M. E. Tucker, "X-ray powder diffraction of sediments," in Techniques in Sedimentology, M. E. Tucker, Ed., p. 394, Blackwell, Oxford, UK, 1998.

[4] C. D. Ruan and C. R. Ward, "Quantitative X-ray powder diffraction analysis of clay minerals in Australian coals using Rietveld methods," Applied Clay Science, vol. 21, no. 5-6, pp. 227240, 2002.

[5] G. M. Friedman, "Identification of carbonate minerals by staining methods," Journal of Sedimentary Petrology, vol. 29, no. 1, pp. 89-97, 1959.

[6] J. A. D. Dickson, "A Modified staining technique for carbonates in thin section," Nature, vol. 205, no. 4971, p. 587, 1965.

[7] R. C. Selley, Applied Sedimentology, Elsevier, Amsterdam, The Netherlands, 2nd edition, 2000.

[8] G. V. Chilingar, H. J. Bissell, and R. W. Fairbridge, Carbonate Rocks: Origin, Occurrence and Classification (Developments in Sedimentology 9A), Elsevier, Amsterdam, The Netherlands, 1967.

[9] C. J. Goss, "The kinetics and reaction mechanism of the goethite to hematite transformation," Mineralogical Magazine, vol. 51, no. 3, pp. 437-451, 1987. 

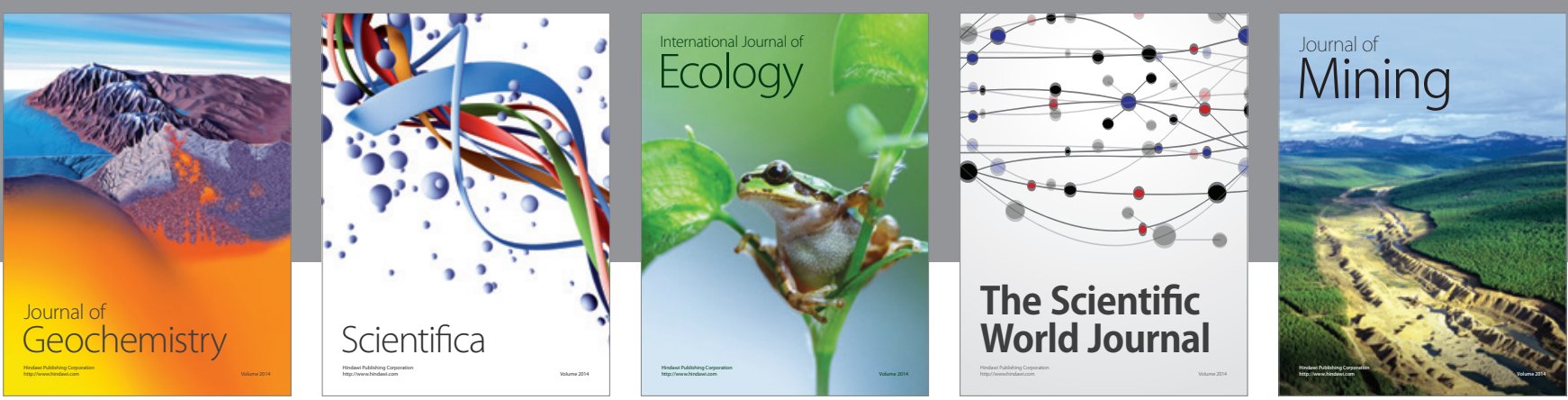

The Scientific World Journal
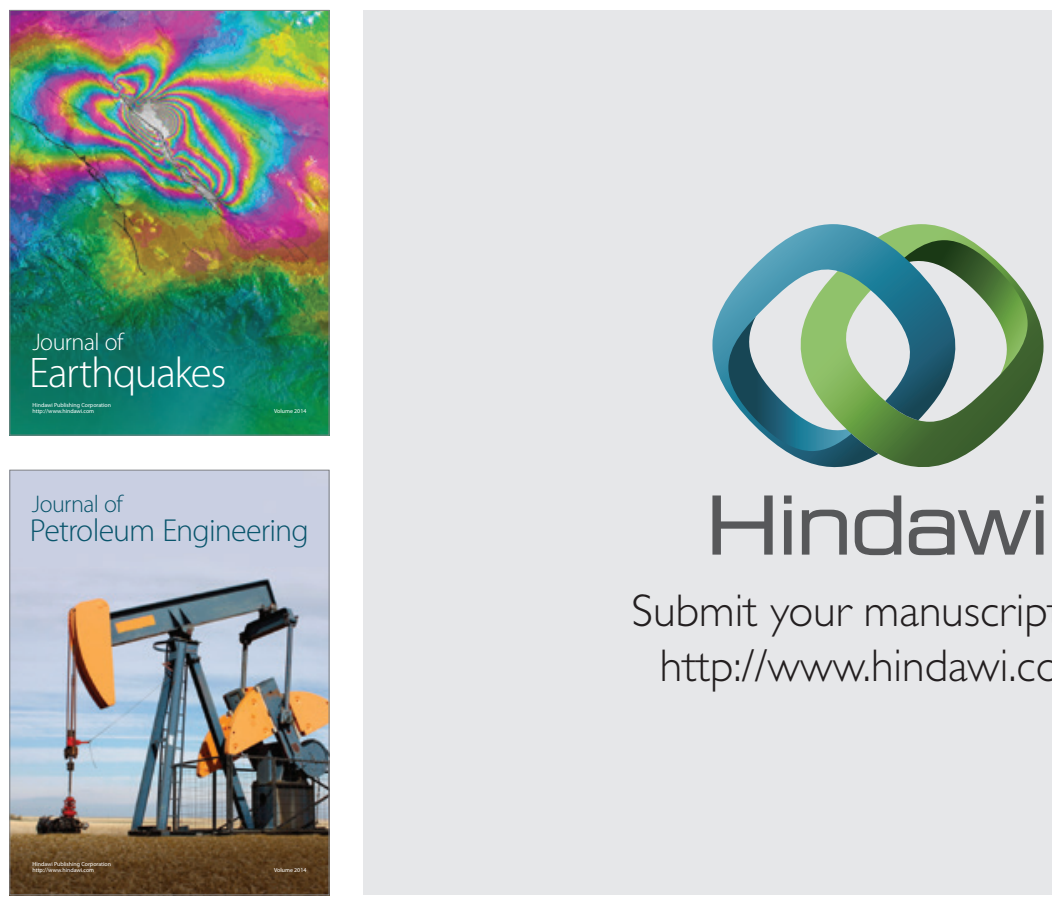

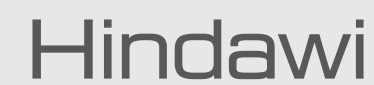

Submit your manuscripts at

http://www.hindawi.com
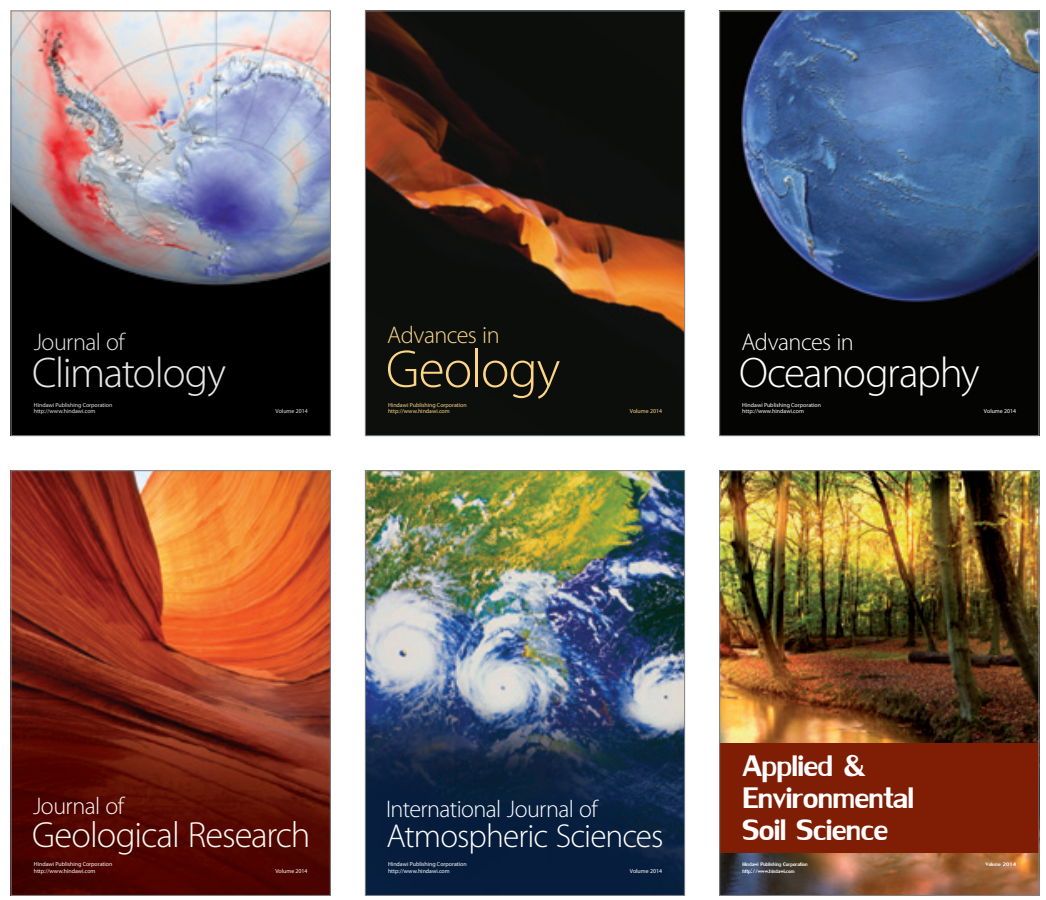
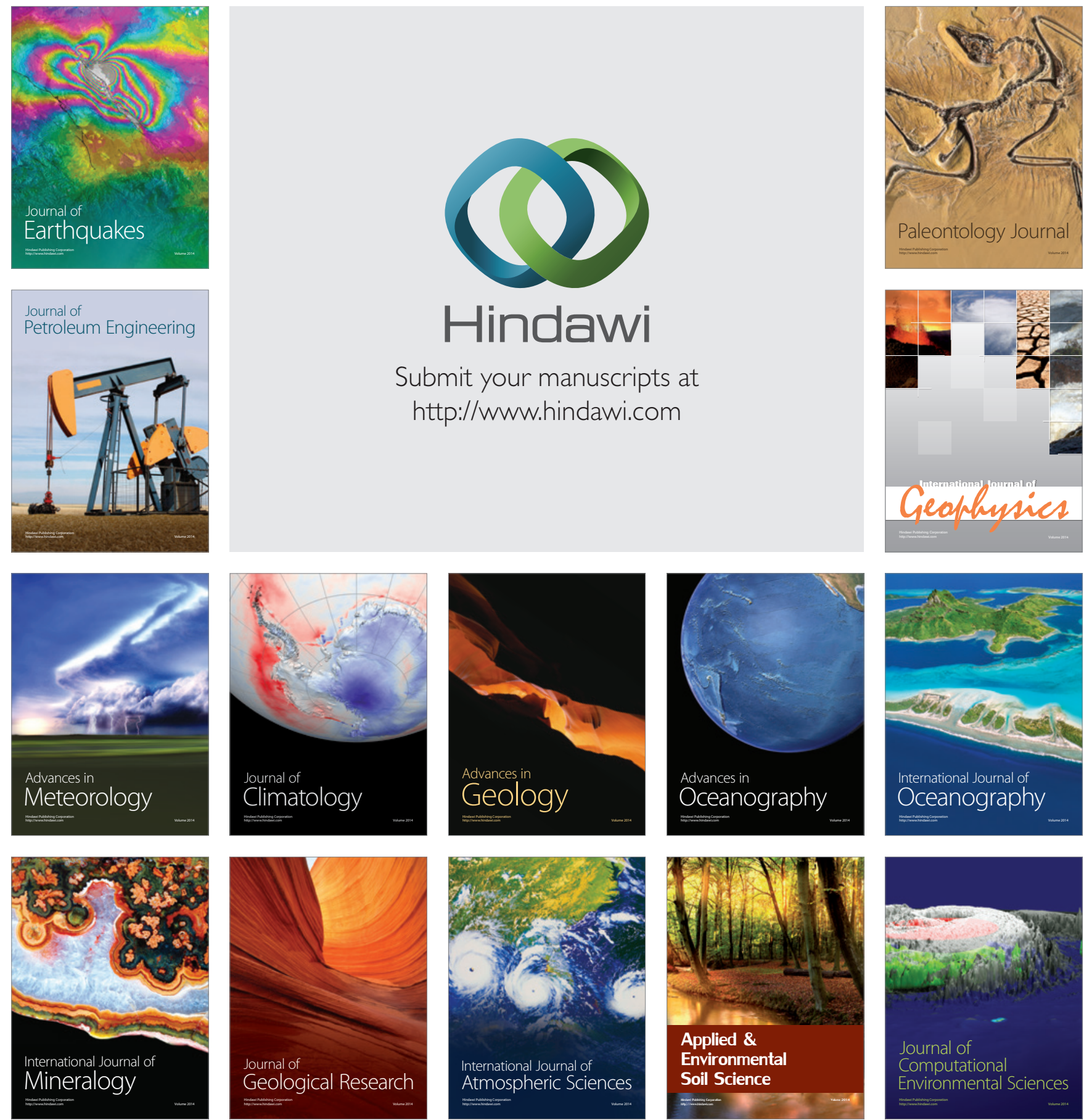